Research Article

\title{
Determinants of the Dairy Technology Adoption by the Rural Milk Producers in District Muzaffarabad, Azad Jammu and Kashmir
}

\author{
Summara Abbasi* and Khalid Nawab
}

Department of Agricultural Extension Education and Communication, the University of Agriculture, Peshawar, Pakistan.

\begin{abstract}
The adoption of dairy technology has a direct impact on the socio-economic development of rural milk producers as milk production has a significant contribution to sustainable rural livelihoods. For this purpose, the present research was conducted to determine the socio-economic factors that influence the rural milk producers in the adoption of dairy technology. A survey was carried out in district Muzaffarabad of Azad Jammu and Kashmir by selecting 8 villages purposively, based on the average number of livestock population i.e 2-3 heads per household, for dairy production. A structured and pretested interview schedule was used to collect the primary data from randomly selected 333 respondents. For analysis of data descriptive statistics and binary logistic model was used through the Statistical Package for Social Sciences (SPSS) and STATA. Information about dairy practices was studied and percentages recorded, about $70 \%$ of the farmers were aware of artificial insemination and vaccination while at least 51\% was reported about livestock management. Improved feeding was very active as $70 \%$ of farmers were well informed followed by breed status recorded by $70 \%$ of the farmers. Demographic results showed that $63 \%$ of respondents were literate with an average age of 51 years and farming experience of upto 11 years. Results from the binary logistic model indicate that number of family members, farm knowledge, accessibility of extension services, gender, credit access, farm size, farming experience, and crossbreeds' availability had a positive association with dairy technology adoption, while age and market distance had a negative association. According to the study results, it is concluded that the adoption of technology depends on their socio-economic conditions. Hence, it is suggested that the administration should encourage a deliberate strategy in building farmers' awareness regarding dairy technology through trainings, demonstrations, field visits, and experience sharing at different levels. The government should provide credit facilities to the farmers in consideration of their socio-economic conditions.

Received | January 01, 2021; Accepted | May 13, 2021; Published | July 01, 2021

*Correspondence | Summara Abbasi, Department of Agricultural Extension Education and Communication, the University of Agriculture, Peshawar, Pakistan; Email: summaraabbasi@gmail.com

Citation | Abbasi, S. and K. Nawab. 2021. Determinants of the dairy technology adoption by the rural milk producers in district Muzaffarabad, Azad Jammu and Kashmir. Sarhad Journal of Agriculture, 37(3): 921-929.

DOI | https://dx.doi.org/10.17582/journal.sja/2021/37.3.921.929

Keywords | Adoption, Dairy technology, Logit model, Rural milk producers, socio-economic
\end{abstract}

\section{Introduction}

$\mathrm{D}$ airy development is considered an influential factor in eradicating poorness and creating prosperity in the developing world. Livestock comprises $30 \%$ of the agricultural Gross Domestic Product (GDP) within the developing world, while about $40 \%$ of the worldwide agricultural GDP, is one amongst the fastest growing subsectors in agriculture (FAO, 2009). Dairy farming is considered a key instrument for improving the financial conditions of farmers in several countries. It is not simply a helpful source of balanced diet and income but is a path for asset accumulation (Sharon, 2011). Besides 
this, it indicates that dairy development has the potential to overcome the poverty level. On the other hand, the dairy setup is becoming gradually more vital and it magnificently improved the rural livelihoods (Quddus, 2012). Dairy farming acts as a cash crop and is considered as white gold of the rural economy. Milk provides fairly fast returns for small scale producers and is an essential source of earning. So, small household dairy producers need to adopt dairy technology to increase milk production and its quality. Dairy development is a key livelihood strategy and a higher level of technology adoption in this sector is directly linked with increased milk protein, poverty alleviation, and ultimately higher income generation (Uddin et al., 2010). The use of improved feed technology, the use of crossbred animals, and improved management are included in dairy technologies (Mohammed et al., 2004).

\section{Determinants of dairy technology adoption}

Adoption is an intellectual procedure and it allows a person to pass from the first hearing regarding an idea towards its final acceptance. This process consists of awareness, interest, evaluation, trial, and adoption stages (Bahadur and Siegfried, 2004). Adoption of any new idea can be considered in two ways: In terms of the figure of farmers who accept the innovation and in terms of the entire area on which the innovation is adopted. Neither of the procedures is naturally better and the option depends on the subject being addressed. If the objective is to conclude how several people have been influenced by innovation, it makes sense to inquire what size of farmers has adopted the innovation. However, if the target is to determine the economic profits to adoption, it clears how extent the area is affected (Morris et al., 2001). The literature regarding technology diffusion and adoption illustrates that several attributes of individuals may motivate them to act in different ways. How and why individuals adopt innovations have inspired a great deal of research and several researchers across different disciplines have established technology adoption models and theories. Many recent studies have confirmed the results of Rogers. According to Rogers (1995), socio-economic characteristics, individuality values, and communication behavior of persons influence their method of adopting ideas such that some individuals accept innovations before others. Researchers (Teshome et al., 2016; Muriu et al., 2017; Tamirat et al., 2018) have confirmed the socioeconomic factors like farmers' age, household size, farm size, formal education, and gender as extremely vital factors in affecting the adoption and utilization of up to date technologies. To enhance the production potential of dairy animals several interventions and technologies have been provided through extension services in the study area so that it can meaningfully contribute to the socio-economic development.

\section{Objectives of the study}

Keeping in view this perspective, the present research study was designed to find out:

- The farmers' perception regarding dairy technology,

- Socio-economic factors that influence rural milk producers in the adoption of dairy technology.

\section{The conceptual framework for dairy technology adoption}

Adoption of dairy technology is considered a livelihood strategy influenced by different socioeconomic factors. The conceptual framework is drawn in Figure 1. Mansfield (1961) called these forces as important driving forces in the technology adoption process. For example, age is a continuous variable measured in number of years. There is an inverse connection among family heads and dairy innovation reception. A unit increase in the age of the household head decreases the chances of reception because they were reluctant to take part in the innovation dispersal process, no doubt because of being more affected by culture. The report by Quddus (2012) expressed that the likelihood of reception diminished with the expansion of time of family heads. Gender is a dummy variable that take an estimation of 1 if the family head was male and 0 generally. Because of numerous social qualities and standards, male have an opportunity of versatility and support in various augmentation programs and thus had more access and exposure to get the data about the dairy innovation and they were settling on choice to receive than what female farmers were doing. Consequently, it is estimated that male farmers are more likely to adopt technology than females (Mesfin, 2005; Taha, 2007). Education is characterized as the number of schooling in years maintained by the respondents. It is a dummy variable and for educated households it took a value of 1 and vice versa. Educated farmers are hypothesized to have better knowledge and information and therefore they will adopt the technology (Haji, 2003). Farm size is a continuous variable and characterized as the overall field region possessed by individual farmers. Farmers having low land were reluctant to accept an 


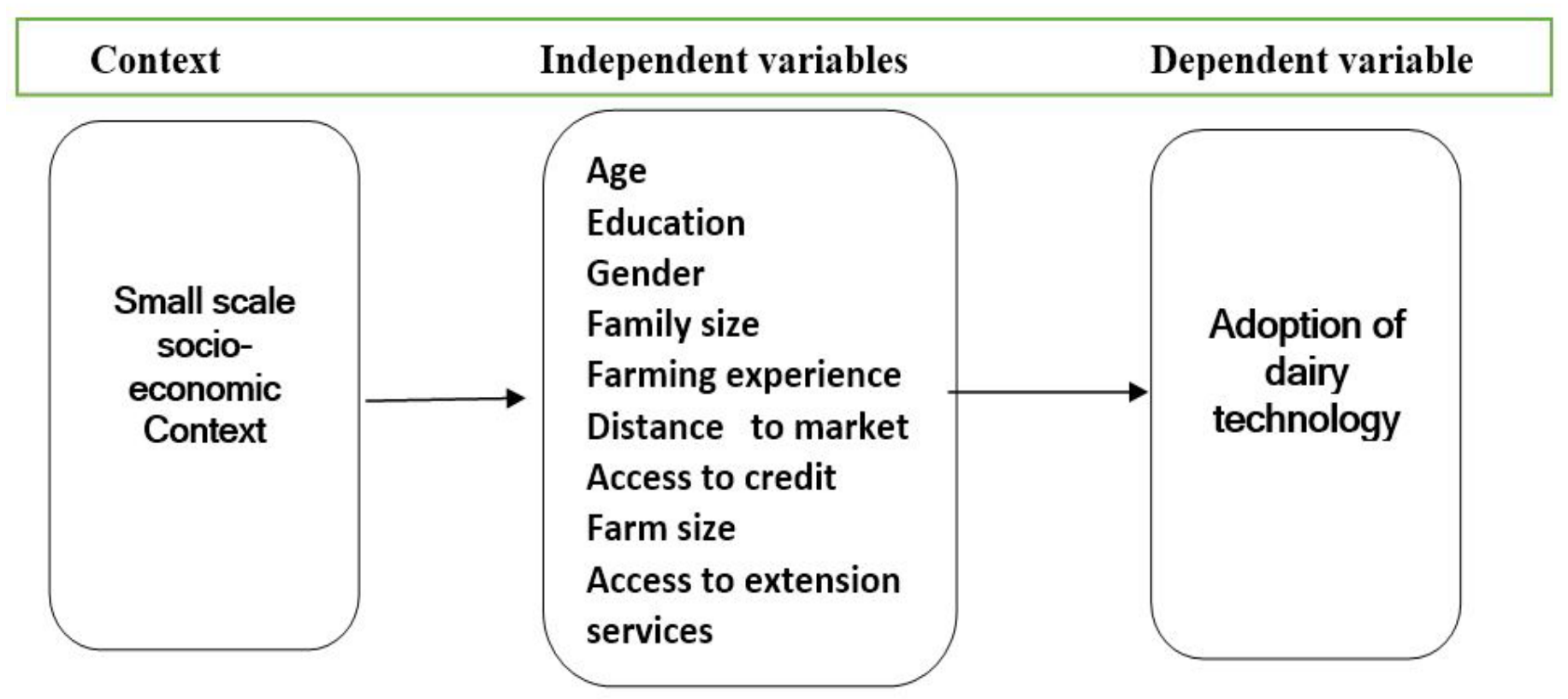

Figure 1: Conceptual framework for the adoption of dairy technology.

innovation package as according to them technology requires large area. Farmers with large land size can receive new innovations than smallholders (Kaba, 2009). Family size is a continuous variable, as dairying is manual labor demanding, therefore, household with more family members tended to have more labor and to adopt dairy technology as compared to ones with less family units which in return improved milk productivity and then milk market contribution of the households. Howley et al. (2012) described that farmers with more children were much more likely to use dairy technology in a certain era. Market distance is assumed to influence the adoption of dairy advances. It is a continuous variable and measured in kilometers. A unit increase in market distance decreases the likelihood adoption of dairy technologies/innovations. As the market is nearer to farm family the transport charges would be low as well as loss due to spoilage. Increase in market distance decreases the intensity of adoption (Dereje, 2006; Rahmeto, 2007). Access to extension services refers to contact between the extension agents and the farmers. This variable is estimated as a dummy variable taking an estimation of 1 if the farmer family unit approached to dairy productivity services and 0 generally. It is estimated that extension access could change and manipulate a farmer's decision to adopt a new technology (Getahun, 2012). Farming Experience is a continuous variable calculated in years. It indicates to the number of years that the smallholder farmer experienced farming activity after the dairy technology transformed to the area. It is assumed that there is a direct affiliation among the farming experience and dairy technology adoption. High experienced farmers were predictable to be eager to adopt a dairy technology since they were receiving information regarding the advantages of dairy technology through various ways (Quddus, 2012). Credit access is considered as a dummy variable having a value of 1 if the household has received credit and 0 otherwise. This variable is assumed to effect the dairy innovation selection because of its cheap price that is beyond the affordability of family members. Credit loosens up the money related requirements of the family unit to contribute on dairying. The finding of Muzari et al. (2012) expressed that the significant choice for increased selection of innovation is to control the pay/capital limitation through expanded credit facility.

\section{Materials and Methods}

Azad Jammu and Kashmir (AJK), Pakistan Administered region, also have hereditary a huge rural financial setup endowed with wealthy natural assets awaiting judicious consumption (Khan and Akram, 2012). In AJK livestock is an essential component of the rural economy as approximately $88 \%$ of rural inhabitants are directly or indirectly concerned with livestock/poultry production. It's not solely the main source of living, however an old custom of poor families. The state of AJK has diversified agroecological zones having favorable surroundings for rearing diverse livestock breeds. The majority of the 
dairy farmers all over the state are reliant on the production of their small herds of buffalo/cattle for income. Therefore, dairying shares considerably the livelihood and food security of the population in the local areas. The area lies between longitudes 73-75 and latitude 33-36. It is comprised of 10 districts. Therefore, a multistage sampling technique was used to draw the required sample. District Muzaffarabad was selected purposively as majority of the dairy farmers of this area are involved in dairy production because of their proximity to government and nongovernment departments which are working on dissemination of dairy technologies. It is comprised of 25 union councils out of these 4 UCs were selected purposively. Then from each union council, 2 villages were selected purposively. The list of villages was prepared in collaboration with the AJK revenue department. Also, the list of milk producers from all selected villages was obtained from the respective district livestock extension department. A technique of proportional allocation sampling was used, to determine the appropriate sample size in each village (Cochran, 1977). The formula for proportional allocation is:

$$
n i=\frac{n}{N} \times N i
$$

$\mathrm{n}=$ total sample size required for the research; $\mathrm{N}=$ total no of livestock farmers in the study area; $\mathrm{ni}=$ selected respondent size from each village; $\mathrm{N}_{i}=$ population of each village. Therefore, a total sample size of 333 households was randomly selected.

The interview schedule was designed according to study objectives to obtain the relevant data from dairy farmers. Farmers' perception regarding the dairy technologies (breeding, feeding, livestock management, and health care practices) was recorded and their awareness was measured in percentage of households. Thus, to find out the influence of different socio-economic factors towards technology adoption logit model was used. For this analysis, the dependent dummy variable was considered as the level of technology adoption while the independent variable includes different socio-economic attributes for the current investigation. To the farmers, 1 was assigned for adopters and 0 for non-adopters. The model gives an empirical estimation of how alteration in these exogenous (dependent) variables impacts the chance of adoption and use to evaluate the usefulness of technology adoption (Nkonya et al., 1997). The binary logit regression model is explained as follows:

$$
\mathrm{Yi}=\operatorname{In}\left(\frac{\mathrm{P}_{\mathrm{i}}}{1-\mathrm{P}_{\mathrm{i}}}\right)=\hat{\mathrm{a}}_{0}+\hat{\mathrm{a}}_{1} \mathrm{X}_{1}+\hat{\mathrm{a}}_{2} \mathrm{X}_{2}+\hat{\mathrm{a}}_{3} \mathrm{X}_{3}+\ldots . \hat{\mathrm{a}}_{\mathrm{K}} \mathrm{X}_{\mathrm{K}}
$$

\section{Where:}

$\left[\mathrm{P}_{\mathrm{i}} / 1-\mathrm{P}_{\mathrm{i}}\right]$ Odds ratio and $\ln \left[\mathrm{P}_{\mathrm{i}} / 1-\mathrm{P}_{\mathrm{i}}\right]$ is called $\log$ odds or logit which act as dependent variable.

$\beta_{0}=$ constant or intercept; $\beta_{1}=$ slope which indicates the change in $\mathrm{y}$ with per unit change in $\mathrm{Xi} ; \beta_{0}-\beta_{3}=$ regression coefficients; $X_{1}$ to $X_{k}=$ independent variables. In the model; dependent variable $\mathrm{Yi}$ : Level of technology adoption ( $1=$ adopters, $o=$ nonadopters).

\section{Results and Discussion}

\section{Farmer's perception regarding dairy technology}

Perception of a particular technology is not the same as adoption. According to Prajapati et al. (2015) four areas of livestock farming such as breeding, feeding, and general management and health care practices are recommended for knowledge. Overall, the awareness level in the study area was quite satisfactory. Table 1 reflects the awareness level of different dairy technology practices in the research area.

The status of breed information was assessed as the result revealed that $70 \%$ were informed about improved breeds and they adopted it for better production of milk. Information status of livestock nutrition was very active as $73 \%$ of household heads were well informed and they used improved feeding systems such as the use of supplemental feed, green grasses, oilseed cakes, and crop residues. About 70\% of respondents were aware and they used it to increase the number of calves. A small number of respondents experienced natural breeding, this might be because of their negative response towards insemination or the non-cooperative nature of extension agents in contacting the farmers. Vaccination, against a few of the general diseases like Heatstroke, Mastitis, FMD (Foot and Mouth Diseases), Hepatitis, Pox, and Hemmorhogic Septicemia also have the highest level (70\%), while $30 \%$ of farmers treated their cows by domestic remedies. A low level of 51\% was reported regarding livestock management. 
Description of the independent variables and the expected outcomes.

$\begin{array}{lll}\text { Variable definition } & \text { Variable type } & \text { Expected sign } \\ \text { Explanatory variables } & & \\ \mathrm{X}_{1:} \text { Age of household head (years) } & \text { Continuous } & - \\ \mathrm{X}_{2:} \text { Education } & \text { Dummy }(0=\text { Illiterate, } 1=\text { literate }) & + \\ \mathrm{X}_{3:} \text { Gender of the household head } & \text { Dummy }(\mathrm{o}=\text { female, } 1=\text { male }) & + \\ \mathrm{X}_{4:} \text { Farming experience (years) } & \text { Continuous } & + \\ \mathrm{X}_{5:} \text { Distance from the market (Kms) } & \text { Continuous } & - \\ \mathrm{X}_{6:} \text { Family size (numbers) } & \text { Continuous } & + \\ \mathrm{X}_{7:} \text { Total land holding (kenals) } & \text { Continuous } & + \\ \mathrm{X}_{8:} \text { Availability of extension services } & \text { Dummy }(0=\text { no, } 1=\text { yes }) & + \\ \mathrm{X}_{9:} \text { Access to credit } & \text { Dummy }(0=\text { no, } 1=\text { yes } & +\end{array}$

Table 1: Farmers information regarding dairy technology.

$\begin{array}{llll}\text { Technology } & \begin{array}{l}\text { Informed/ } \\ \text { Un-informed }\end{array} & \begin{array}{l}\text { No. of re- } \\ \text { spondents }\end{array} & \mathbf{\%} \\ \text { Improved breeds } & \text { Yes } & 233 & 70 \\ \text { (Cross-breeds) } & \text { No } & 100 & 30 \\ \text { Artificial } & \text { Yes } & 233 & 70 \\ \text { Insemination } & \text { No } & 100 & 30 \\ \text { Livestock } & \text { Yes } & 170 & 51 \\ \text { management } & \text { No } & 163 & 49 \\ \text { Improved feeding } & \text { Yes } & 246 & 73 \\ & \text { No } & 87 & 27 \\ \text { Animal Health } & \text { Yes } & 233 & 70 \\ \text { (Vaccine) } & \text { No } & 100 & 30 \\ \text { Overall } & & 333 & 100\end{array}$

Source: Field Survey, 2018.

\section{Demographic characteristics}

The average household age was 51 years and the mean number of family size was seven. The average farming experience of the households was 11 years. The proportion of male-headed households was 54\%. Almost, $63 \%$ of the households were literate and know the basic idea of dairy technology adoption. However, the adoption of crossbreed animals is $70 \%$. The majority of the interviewed household heads $(67 \%)$ indicated the availability of animal health services in the study area.

Before running the model, all the exogenous variables were checked for the existence of multicollinearity. The correlation matrix was constructed for the independent variables using STATA output, is given in Table 3. According to Hamilton (2006) and Gujarati (2003) occurrence of multicollinearity becomes trouble, if the value of correlation among the covariates enlarged 0.8 otherwise it is satisfactory.

The value of correlation lies between -1 to +1 , near to 1 is strongest. Table 3 indicated no multicollinearity problem as among all the independent variables values of correlation coefficients are lower than 0.5 and this shows a weak correlation among the study variables.

Table 2: Descriptive statistics of the variables.

\begin{tabular}{|c|c|c|}
\hline Definition of variable & Mean & $\begin{array}{l}\text { Std. De- } \\
\text { viation }\end{array}$ \\
\hline Age of the household head (years) & 51.28 & 7.21 \\
\hline Educational status ( $0=$ Illiterate, $1=$ literate $)$ & .627 & .484 \\
\hline $\begin{array}{l}\text { Gender of the household head ( } o=\text { female, } \\
1=\text { male) }\end{array}$ & .549 & .498 \\
\hline Farming experience (years) & 11.05 & 4.084 \\
\hline Family size (number) & 7.435 & 2.023 \\
\hline Total land holding (kenals) & 6.261 & 2.225 \\
\hline $\begin{array}{l}\text { Availability of veterinary services }(0=\text { no, } \\
1=y e s)\end{array}$ & .669 & .4710 \\
\hline Access to Credit $(0=$ no, $1=y e s)$ & .567 & .4961 \\
\hline Distance from the market (Kms) & 9.579 & 5.818 \\
\hline Adoption of cross breed animal ( $0=$ no, $1=y e s)$ & .705 & .456 \\
\hline
\end{tabular}

Source: Field Survey, 2017.

\section{Results for variables used in the logit model}

The statistical tool STATA was used to approximate the Logit model. Generally, for a binary choice of results standard linear regression model (Logit model) is used. As technology adoption (cross-breed) was the dependent variable and it is dichotomous (adopter $=1$, non-adopter $=0$ ) in nature while the socio-economic attributes were the independent variables. The expected coefficients for each explanatory variable, their t-statistics, $\mathrm{p}$-values, and odds ratios were set in Table 4. Odd ratios were used to calculate coefficients of explanatory variables about its impact on the adoption of dairy technology. If the odds ratio were less than one the technology adoption decreases and shows a negative association but if greater than the likelihood of technology adoption increases with a positive association. The selected level of statistical 
Table 3: Collinearity diagnostics for variables used in the logit model.

\begin{tabular}{|c|c|c|c|c|c|c|c|c|c|}
\hline & Age & $\begin{array}{l}\text { Educa- } \\
\text { tion }\end{array}$ & Gender & $\begin{array}{l}\text { Family } \\
\text { size }\end{array}$ & $\begin{array}{l}\text { Farming } \\
\text { experiences }\end{array}$ & $\begin{array}{l}\text { Market } \\
\text { distance }\end{array}$ & Credit & land & $\begin{array}{l}\text { Contact with } \\
\text { extension }\end{array}$ \\
\hline Age & 1.0000 & & & & & & & & \\
\hline Education & -0.2847 & 1.0000 & & & & & & & \\
\hline Gender & -0.0976 & 0.2842 & 1.0000 & & & & & & \\
\hline Family size & -0.0101 & 0.3446 & 0.2565 & 1.0000 & & & & & \\
\hline Farming experiences & 0.2834 & 0.2515 & 0.3755 & 0.4174 & 1.0000 & & & & \\
\hline Market distance & 0.0938 & -0.3079 & -0.2790 & -0.2983 & -0.2259 & 1.0000 & & & \\
\hline Credit & -0.3307 & 0.3131 & 0.2538 & 0.2607 & 0.0923 & -0.2229 & 1.0000 & & \\
\hline Land & -0.0824 & 0.2155 & 0.4191 & 0.4042 & 0.2822 & -0.2375 & 0.2710 & 1.0000 & \\
\hline Contact with extension & -0.3118 & 0.4529 & 0.3082 & 0.3645 & 0.2462 & -0.3689 & 0.4803 & 0.3830 & 1.0000 \\
\hline
\end{tabular}

significance was $5 \%$ and $10 \%$ respectively. The Loglikelihood Ratio (LR) Statistics is about 45.69 follows the chi-square distribution and was also found to be significant at the $5 \%$ level (Table 4).

Table 4: Binary Logit Model estimates for determinants of dairy technology adoption.

\begin{tabular}{|c|c|c|c|c|c|}
\hline Vari & $\begin{array}{l}\text { Coeffi- } \\
\text { cient }\end{array}$ & $\begin{array}{l}\text { Standard } \\
\text { error }\end{array}$ & $Z$ & Sig. & $\begin{array}{l}\text { Odds } \\
\text { ratio }\end{array}$ \\
\hline Age & -.1845 & .0473 & -3.90 & $0.000^{*}$ & .8314 \\
\hline Education & 1.6706 & .5940 & 2.81 & $0.005^{*}$ & 5.315 \\
\hline Family size & .9918 & .2223 & 4.46 & $0.000^{*}$ & 2.695 \\
\hline Gender & 2.352 & .7567 & 3.211 & $0.002^{*}$ & 10.50 \\
\hline Farming experience & .3608 & .0990 & 3.64 & $0.000^{*}$ & 1.434 \\
\hline Distance to market & -.2617 & .0609 & -4.30 & $0.000^{*}$ & .7696 \\
\hline Access to credit & 1.1083 & .6579 & 1.68 & $0.092^{* * *}$ & 3.029 \\
\hline $\begin{array}{l}\text { Access to extension } \\
\text { services }\end{array}$ & 1.6802 & .7767 & 2.16 & $0.031^{*}$ & 5.366 \\
\hline Farm size & .2978 & .1752 & 1.70 & $0.089^{\text {*** }}$ & 1.347 \\
\hline
\end{tabular}

Source: Field Survey (2017). Number of observations $=333$, Dependent variable $=$ adoption of technology; ${ }^{*},{ }^{*}$ indicates statistical significance at $5 \%$ and 10\%; Statistics: LR chi2 (9) $=312.18$; Prob > chi2 = 0.0000; Log-likelibood $=-45.691147 ;$ Pseudo R2 $=0.7736$.

The effect of each explanatory variable is discussed below:

Household head age was significantly and negatively $(\mathrm{P}<0.05)$ related to farmers' likelihood to adopt dairy technology (cross-breed). As the household head's age increased by a year, the probability that the household adopts dairy technology decreased. This means the log of odds in favor of adoption goes down. The negative sign for the age coefficient explains that aged farmers will tend to ignore improved methods and continue to use simple technologies they know already while young farmers, being adventurous, may tend to try new and improved technologies to increase production. This outcome is parallel to the result of Quddus (2012) who confirmed that the possibility of cross-breed adoption decreased with the increase in heads age. According to Karidjo et al. (2018) statement age is also negatively and significantly associated with adoption at a $01 \%$ level of significance.

Adoption of dairy technology was positively associated with farmers' education. This was found to be significant at the percent 5 level. The odds ratios indicate the educated farmers more likely to adopt dairy technology as compared to illiterate farmers. According to Cicek et al. (2007) educational level participates positively in the implementation of scientific innovation in dairy cattle breeding.

Family size has a positive and significant association with households' possibility to accept technology at $5 \%$ significance level. The positive sign of coefficient and odds ratios explained that when the family member increased by one, the farmer's probability in dairy technology increased. According to Shiferaw and Holden (1998) large family size can relax the labor constraints and is expected to affect the decision of adopting dairy technologies positively.

The farming experience was found to have a positive and significant association with farmers' likelihood to adopt dairy technology at 5\% significance level. The positive sign of coefficient and odds ratios explained that as the household head's farm experience increased by a year, the probability that the household adopts dairy technology also increased. The finding is parallel with Quddus (2012) who found that adoption of dairy technology is positively associated with farming experience. 
Gender was found to be positively and significantly $(\mathrm{P}<0.05)$ related to the adoption of dairy technology by farm households. According to odds ratios, male farmers are more likely to adopt technology than their female counterparts. As males have greater access to information they make decisions on useful assets such as land, labor, and capital which are vital for adoptions. This result is in agreement with those of Akudugu et al. (2012) who found significant effects of gender on technology adoption in Ghana.

Credit was found to be significant at the $10 \%$ level. This outcome is in line with Abdulai (2016) who found a significant and positive effect of access to credit on the adoption of innovations. For technology, the adoption credit is a significant motivating factor.

To promote adoption of present agricultural technology access to extension services is important because it can balance the negative consequence of lack of years of formal education in the overall decision to adopt some technologies (Yaron et al., 1992). Access to extension services, therefore, creates the platform for the acquisition of the relevant information that promotes technology adoption. The coefficient estimates and odds ratios for contact with extension services were found to be positive and significantly $(p<0.05)$ related to the household's likelihood to adopt dairy technology. According to Azumah et al., (2017) adoption level was expected to be higher and positively influence farmers' access to information.

Distance to market was negatively and significantly $(p<0.05)$ associated with farmers' likelihood to adopt dairy technology. This means a unit increase in distance decreases the chances of adoption. This finding is similar to the report of Dehinenet (2014) that indicates an increase in market distance decreased the adoption.

From the analysis carried out in this study, it is seen that the size of land holdings of dairy farmers positively influences the decision to adopt dairy technology. This was found to be significant at the $10 \%$ level of significance. The odds ratios described that inequality of land distribution among the farmers influences unequally the decision to adopt dairy technology. This judgment is in line with the writing that small farmers are reluctant in accepting new ideas as compared to large ones (McNamara et al., 1991; Abara and Singh, 1993; Feder et al., 1985).

\section{Conclusions and Recommendations}

It is concluded that the farmers' perception regarding the dairy technology in the study area was found quite satisfactory. The core finding of the research was that the frequency of the extension agents' visits can positively affect the adoption decision. Results of binary logistic regression show that adoption of dairy crossbreed animals was found to be influenced by the family size, farming experience, availability of extension services, access to credit, and education of the household head in the study area. Age and market distance was found negative but significantly associated with technology adoption. Hence, it is recommended that:

- Diffusing dairy technologies should be supported by the government livestock department and also enabled them to utilize the technologies in a better way.

- There should be proper monitoring to identify the related issues which cause hindrance in technology adoption.

- Village level extension workers should pay regular visits to the farms/homes of dairy farmers.

- There is a desire for technical and institutional trainings for senior farmers on technology adoption.

\section{Acknowledgments}

This manuscript is a part of the Ph.D. dissertation of the principal author submitted to the University of Agriculture Peshawar, Pakistan.

\section{Novelty Statement}

The novelty of this research is the impact of technology adoption in improving livelihood through extension services in District Muzaffarabad, AJK. Artificial insemination was found dominated in the study area due to its vital role in the genetic makeup of the breeds.

\section{Author's Contribution}

Summara Abbasi (principal author/Ph.D. scholar) conducted research, collected data, made analysis and wrote this manuscript. Khalid Nawab (major supervisor) guided and supervised the whole research study. 
Conflict of interest

The authors have declared no conflict of interest.

\section{References}

Abara, I.O.C. and S. Singh. 1993. Ethics and biases in technology adoption: The small farm argument. Technol. forecast. Soc. Change, 43(4): 289-300. https://doi.org/10.1016/00401625(93)90057-E

Abdulai, A.N. 2016. Impact of conservation agriculture technology on household welfare in Zambia. Agric. Econ., 47(6): 729-741. https:// doi.org/10.1111/agec.12269

Akudugu, M.A., E. Guo and S.K. Dadzie. 2012. Adoption of modern agricultural production technologies by farm households in Ghana: What factors influence their decision? J. Biol. Agric. Healthc., 2(3): 1-13.

Azumah, S.B., S.A. Donkoh and I.G.K. Ansah. 2017. Contract farming and the adoption of climate change coping and adaptation strategies in the northern Region of Ghana. Environ. Dev. Sustain., 19(6): 2275-2295. https://doi. org/10.1007/s10668-016-9854-z

Bahadur, K.L. and B. Siegfried. 2004. Technology adoption and household food security. Analyzing factors determining technology adoption and impact of project intervention. A Case of Smallholder Peasants in Nepal, Paper prepared for presentation at the Deutscher Tropentag, Humboldt University, Berlin. 3(1): 65-70.

Cicek, H., M. Tandogon, Y. Terzi and M. Yardimci. 2007. Effects of some technical and socioeconomic factors on milk production costs in dairy enterprise in Western Turkey. World J. Dairy, 2(2): 69-73.

Cochran, W.G. 1977. Sampling techniques, $3^{\text {rd }}$ Edition. John Wiley and Sons, New York. pp. 37- 40.

Dehinenet, G., 2014. Analyses of impact of improved dairy technology adoption on Smallholder household livelihoods and milk value chain in selected zones of Oromia and Amhara National Regional States, Ethiopia. A dissertation submitted to the college of Veterinary Medicine and Agriculture, Addis Ababa University. Thesis of Doctor of Philosophy in Animal production. pp. 35-45.

Dereje, H. 2006. Assessment of farmers' evaluation criteria and adoption of improved bread wheat varieties in Akaki. M.Sc. thesis submitted to School of Graduate Studies of Haramaya University, central Ethiopia. pp. 80-90.

FAO. 2009. State of food and agriculture: Livestock in the balance, Rome: FAO, Accessed on $5^{\text {th }}$ September, 2011. http://ftp.fao.org/docrep/ fao/012/i0876e /i0876e.pdf

Feder, G., E.R. Just and D. Zilberman. 1985. Adoption of agricultural innovations in developing countries: A survey. Econ. Dev. Cult. Change, 33(2): 255-298. https://doi. org/10.1086/451461

Getahun, D. 2012. Assessment of the livestock extension service in Ethiopia. The case of Southern region. Int. J. Sci. Technol. Res., 1(10): 10-16.

Gujarati, D.N. 2003. Basic Econometrics, $3^{\text {rd }}$ ed. McGraw-Hill USA. pp. 78-79.

Haji, B. 2003. Adoption of crossbred dairy cows in Aris Zone, The case of Tiyo and Lemu Bilbilo Woreds. MSc. Thesis presented to the School of Graduate Studies of Alemaya University, Ethiopia. pp. 70-95.

Hamilton, L.C. 2006. Statistics with Stata. Thomson Brooks/Cole USA. pp. 45-50.

Howley, P., C.O. Donoghue and K. Heanue. 2012. Factors affecting farmers' adoption of agricultural innovations: A panel data analysis of the use of artificial insemination among dairy farmers in Ireland. J. Agric. Sci., 4: 171-179. https://doi.org/10.5539/jas.v4n6p171

Kaba, M. 2009. Analysis of the gender disparity in agricultural extension service delivery. The Case of Gedeb Woreda, West Arsi Zone, Oromia Regional State. M.Sc. Thesis presented to School of Graduate Studies of Haramaya University, Ethiopia. pp. 45-50.

Karidjo, B.Y., Z. Wang, Y. Boubacar and C. Wei. 2018. Factors influencing farmers' adoption of soil and water control technology (SWCT) In Keita Valley, a semi-arid area of Niger. Sustain., 10(2): 250-288. https://doi.org/10.3390/ su10020288

Khan, A. and M. Akram. 2012. Farmers perception of extension methods used by extension personnel for dissemination of new agricultural technologies in Khyber Paktunkhwa: Pakistan. Sarhad J. Agric., 28(3): 511-520.

Mansfield, E. 1961. Technical change and the rate of imitation. Econometrica: J. Econ. Soc., pp. 
741-766. https://doi.org/10.2307/1911817

McNamara, K.T., M.E. Wetzstein and G.K. Douce. 1991. Factors affecting peanut producer adoption of integrated pest management. Rev. Agric. Econ., 13: 129-139. https://doi. org/10.2307/1349563

Mesfin, A. 2005. Analyses of factors influencing adoption of Triticaie (Xtriticoseale Witmact) and impact: The case of Farta Wereda. M.Sc. thesis submitted to School of Graduate Studies of Haramaya University. pp. 60-75.

Mohammed, A.M., A.S. Ehui and Y. Assefa. 2004. Dairy development in Ethiopia. EPTD discussion paper No. 123. Int. Food Policy Res. Institute. Washington, DC. U.S.A. pp. 40-48.

Morris, M.L., R. Tripp and A.A. Dankyi. 2001. Adoption and impacts of improved maize production technology: A case study of the Ghana Grains Development Project" Economics Program Paper 99-01. Mexico, D.F. CIMMYT. pp. 37-45.

Muriu, F.W., M. Mucheru-Muna, F. Waswa and F.S. Mairura. 2017. Socio-economic factors influencing utilization of rain water harvesting and saving technologies in Tharaka South, Eastern Kenya. Agric. Water Mgt., 194: 150-159. https://doi.org/10.1016/j. agwat.2017.09.005

Muzari, W., W. Gatsi and S. Muvhunzi. 2012. The impacts of technology adoption on smallholder agricultural productivity in Sub-Saharan Africa: A review. J. Sustain. Dev., 5: 69-77. https://doi. org/10.5539/jsd.v5n8p69

Nkonya, E., T. Schroeder and D. Norman. 1997. Facors affecting adoption of improved maize seed and fertilizer in Norhern Tanzania. J. Agric. Econ., 48: 1-12. https://doi. org/10.1111/j.1477-9552.1997.tb01126.x

Prajapati,V.S., R.R.Singh,S.S.Choudhary and N.B. Patal. 2015. Knowledge level of dairy farmers regarding recommended dairy management practices. Livest. Res. Int., 3(4): 82-84.

Quddus, M.A. 2012. Adoption of dairy farming technologies by small farm holders: Practices and constraints. Bangladesh J. Anim. Sci.,
41(2): 124-135. https://doi.org/10.3329/bjas. v41i2.14132

Rahmeto, N. 2007. Determinants of adoption of improved Haricot Bean production package in Alaba Special Woreda. M.Sc. thesis submitted to School of Graduate Studies of Haramaya University, Southern Ethiopia. pp. 90-105.

Rogers. E.M.,1995. Diffusion of Innovations. $4^{\text {th }}$ ed., New York: The Free Press. pp. 95.

Sharon, N.M.N. 2011. Pathways to technology adoption: Understanding smallholders dairy farmers in Southern Zambia. Masters of arts in development studies. The Hague, the Netherlands. pp. 126-128.

Shiferaw, B. and S.T. Holden. 1998. Resource degradation and adoption of land conservation technologies in the Ethiopian highlands: A case study in Andit Tid, North Shewa. Agric. Econ., 18(2): 233-247. https://doi. org/10.1111/j.1574-0862.1998.tb00502.x

Taha, M., 2007. Determinants of intensity of adoption of improved onion production package in Dugda Bora District, East Showa, Ethiopia. M.Sc. thesis submitted to School of Graduate studies, Haramaya University. pp. 20-55.

Tamirat, T.W., S.M.Pedersen and K.M. Lind. 2018. Farm and operator characteristics affecting adoption of precision agriculture in Denmark and Germany. Acta. Agric. Scand. B-S. P., 68(4): 349-357. https://doi.org/10.1080/09064 710.2017 .1402949

Teshome, A., J. de Graaff and M. Kassie. 2016. Household-level determinants of soil and water conservation adoption phases: Evidence from North-Western Ethiopian Highlands. Environ. Mgt., 57(3): 620-636. https://doi.org/10.1007/ s00267-015-0635-5

Uddin, M.M., M.N. Sultana, A. Ndambi, T. Hemme and K.J.Peters. 2010. A farm economic analysis in different dairy production systems in Bangladesh. Livest. Res. Rural Dev., pp. 124.

Yaron, D., A. Dinar and H. Voet. 1992. Innovations on family farms: The Nazareth Region in Israel. Am. J. Agric. Econ., 4(2): 361-370. https://doi. org/10.2307/1242490 